\title{
МОРФОТЕКТОНИКА, СЕЙСМИЧНОСТЬ И ЭКЗОГЕННЫЕ ПРОЦЕССЫ КОЛЬСКОГО ПОЛУОСТРОВА
}

Шварев С. В.

\begin{abstract}
Аннотация
Целями работы являются выявление морфологически выраженной разломно-блоковой структуры, отождествляемой с новейшим тектоническим этапом, и сопоставление её с участками проявлений экзогенных процессов, современной, исторической и палеосейсмичности для установления активизированных в постледниковое время разломов.
\end{abstract}

На основе анализа космических снимков (Landsat-ETM+) и цифровой модели рельефа (GTOPO-30) проведено морфоструктурное дешифрирование территории Кольского полуострова и прилегающей части Северной Карелии с выделением морфолинеаментов и элементарной блоковой структуры. Анализ направлений и протяженности элементарных, единичных (простых) и сложных (эшелонированных, параллельно-сопряженных, кулисных) линейных структур и их зон показал, что как для линейных (разломных), так и площадных (блоковых) структур характерно преобладание единой системы северо-западных и северо-восточных разностей с явным доминированием первых, и одномодальное распределение протяженности разломов и площади блоков в зависимости от их количества. Это свидетельствует о едином (новейшем) этапе формирования морфотектонического облика территории и об отсутствии дискретной иерархии морфоструктур. Рассчитана степень раздробленности территории на разных глубинах в зависимости от количества и протяженности морфолинеаментов. Определена высокая степень унаследованности морфолинеаментов архейско-протерозойской структуре ( $50 \%)$. Элементарные морфотектонические блоки группируются в составные блоки, ограниченные линейными зонами большой протяженности (100 - 600 км), обладающими индивидуальными физиономическими чертами, определяемыми рисунком разрывов, свидетельствующими о характере новейшей динамики и степени унаследованности или переформирования структурного плана.

На основе анализа топографических карт масштаба 1:100000, а также каталогов исторических и палеоземлетрясений, а также сводных литературных и собственных данных по палеосейсмодеформациям, определена локализация проявлений ЭГП, очагов палео-, исторических и современных землетрясений. Составлена геоинформационная база с помощью которой проведено моделирование пространственного распределения эндо- и экзогенных признаков тектонической активности и сопоставление с новейшей разломно-блоковой структурой. Выявлено пространственное подобие зон эндогенной и экзогенной активизации и приуроченность их к разломам, определяемым как активизированные в постледниковое время.

Установлено, что наиболее активны в постледниковье-голоцене: а) фланговые элементы Кольского полуострова - вдоль Баренцевоморского побережья, берегов Кандалакшского залива и Горла Белого моря; б) центральная (узловая) часть с Хибинским и Ловозерским массивами; в) субмеридионально (поперечно) секущие структуры, отделяющие восточную часть полуострова от западной (Хибины - Кола и Хибины - Нива).

Пространственные параметры активизированных зон свидетельствуют о диапазоне силы землетрясений, порождаемых этими структурами [6.5-7.5 как в постледниковое время, так и в неоплейстоцене в целом.

\section{Ключевые слова:}

Кольский полуостров, морфотектоника, активные разломы, новейшая разломно-блоковая структура, морфолинеаменты, сейсмичность, палеоземлетрясения, экзогенные процессы 


\title{
УДК 551.24+551.43
}

\section{МОРФОТЕКТОНИКА, СЕЙСМИЧНОСТЬ И ЭКЗОГЕННЫЕ ПРОЦЕССЫ КОЛЬСКОГО ПОЛУОСТРОВА}

\author{
Шварев C.В. ${ }^{1,2}$ \\ ${ }^{1}$ Институт географии РАH; shvarev@igras.ru; \\ ${ }^{2}$ Институт физики Земли им. О. Ю. Шмидта РАН; shvarev@ifz.ru

\section{MORPHOTECTONICS, SEISMICITY AND EXOGENOUS PROCESSES OF THE KOLA PENINSULA}

\author{
Shvarev S.V. ${ }^{1,2}$ \\ ${ }^{1}$ Institute of Geography, RAS; shvarev@igras.ru; \\ ${ }^{2}$ Schmidt Institute of Physics of the Earth, RAS; shvarev@ifz.ru
}

\begin{abstract}
АННОТАЦИЯ
Целями работы являются выявление морфологически выраженной разломноблоковой структуры, отождествляемой с новейшим тектоническим этапом, и сопоставление её с участками проявлений экзогенных процессов, современной, исторической и палеосейсмичности для установления активизированных в
\end{abstract} постледниковое время разломов.

На основе анализа космических снимков (Landsat-ETM+) и цифровой модели рельефа (GTOPO-30) проведено морфоструктурное дешифрирование территории Кольского полуострова и прилегающей части Северной Карелии с выделением морфолинеаментов и элементарной блоковой структуры. Анализ направлений и протяженности элементарных, единичных (простых) и сложных (эшелонированных, параллельно-сопряженных, кулисных) линейных структур и их зон показал, что как для линейных (разломных), так и площадных (блоковых) структур характерно преобладание единой системы северо-западных и северо-восточных разностей с явным доминированием первых, и одномодальное распределение протяженности разломов и площади блоков в зависимости от их количества. Это свидетельствует о едином (новейшем) этапе формирования морфотектонического облика территории и об отсутствии дискретной иерархии морфоструктур. Рассчитана степень раздробленности территории на разных глубинах в зависимости от количества и протяженности морфолинеаментов. Определена высокая степень унаследованности морфолинеаментов архейско-протерозойской структуре $(\approx 50 \%)$. Элементарные морфотектонические блоки группируются в составные блоки, ограниченные линейными зонами большой протяженности (100 - 600 км), обладающими индивидуальными физиономическими чертами, определяемыми рисунком разрывов, свидетельствующими о характере новейшей динамики и степени унаследованности или переформирования структурного плана.

На основе анализа топографических карт масштаба 1:100000, а также каталогов исторических и палеоземлетрясений, а также сводных литературных и собственных данных по палеосейсмодеформациям, определена локализация проявлений ЭГП, очагов палео-, исторических и современных землетрясений. Составлена геоинформационная база с помощью которой проведено моделирование пространственного распределения эндо- и экзогенных признаков тектонической активности и сопоставление с новейшей разломноблоковой структурой. Выявлено пространственное подобие зон эндогенной и экзогенной активизации и приуроченность их к разломам, определяемым как активизированные в постледниковое время.

Установлено, что наиболее активны в постледниковье-голоцене: а) фланговые элементы Кольского полуострова - вдоль Баренцевоморского побережья, берегов 
Кандалакшского залива и Горла Белого моря; б) центральная (узловая) часть с Хибинским и Ловозерским массивами; в) субмеридионально (поперечно) секущие структуры, отделяющие восточную часть полуострова от западной (Хибины - Кола и Хибины - Нива).

Пространственные параметры активизированных зон свидетельствуют о диапазоне силы землетрясений, порождаемых этими структурами $\approx 6.5-7.5$ как в постледниковое время, так и в неоплейстоцене в целом.

Ключевые слова: Кольский полуостров, морфотектоника, активные разломы, новейшая разломно-блоковая структура, морфолинеаменты, сейсмичность, палеоземлетрясения, экзогенные процессы

\section{ANNOTATION}

The purpose of this work is to identify a morphologically pronounced fault-block structure identified with the latest tectonic stage, and compare it with areas of exogenous processes, epicenters, and zones of modern, historical, and paleoseismicity in order to establish faults that were activated in the postglacial period.

Based on the analysis of satellite images (Landsat-ETM+) and a digital terrain model (GTOPO-30) morphotectonic interpretation of the territory of the Kola Peninsula and the adjacent part of North Karelia was performed, with the identification of morpholineaments and an elementary block structure. Analysis of the directions and extent of elementary, single (simple) and complex (echeloned, parallel-conjugate) linear structures and their zones showed that both linear (fault) and areal (block) structures are characterized by the predominance of a single system of North-Western and North-Eastern differences with a clear dominance of the former, and a single-modal distribution of the length of faults and the area of blocks depending on their number. This indicates a single (recent) stage in the formation of the morphotectonic appearance of the territory and the absence of a discrete hierarchy of morphostructures. The degree of fragmentation of the territory at different depths is calculated depending on the number and length of morpholineaments. A high degree of inheritance of morpholineaments in the Archean-Proterozoic structure $(\approx 50 \%)$ was determined. Elementary morphotectonic blocks are grouped into composite blocks, bounded by linear zones of great extent, which have individual physiognomic features defined by the pattern of faults, indicating the nature of the latest dynamics and the degree of inheritance or reformation of the structural plan.

Based on the analysis of topographic maps of 1:100000 scale, as well as catalogues of historical and paleoearthquakes and summary literature and own data on paleoseismic deformations, the localization of modern manifestations of EGP, areas with characteristic landforms indicating EGP and seismic deformations, as well as earthquake foci is determined. The geo-information base has been compiled for modeling the spatial distribution of endo-and exogenous signs of tectonic activity and comparing them with the fault-block structure. The spatial similarity of the zones of endogenous and exogenous activation and their association with a part of the faults identified as activated in the postglacial period are revealed.

Most active in the Post Glacial - Holocene period: a) the flanking elements of the Kola Peninsula along the Barents sea coast, the coasts of the Kandalaksha Gulf and Throat of the White sea; b) Central (hub) part of the Khibiny and Lovozero massifs; C) sub-meridional (transverse) secant structure that separates the Eastern part of the Kola Peninsula from the Western (Khibiny - Kola and Khibiny - Niva directions).

The spatial parameters of the activated zones indicate the range of earthquake magnitudes generated by these structures 6.5-7.5 both in the postglacial period and in the neo-Pleistocene as a whole.

Key words: Kola Peninsula, morphotectonics, morphostructure, active faults, latest fault-block structure, morpholineaments, seismicity, paleoearthquakes, exogenous processes

\section{ВВЕДЕНИЕ}


Кольский полуостров с маломощным чехлом четвертичных отложений, залегающих непосредственно на породах фундамента, давно стал полигоном для изучения и констатации блокового строения литосферы. Еще в трудах А.П. Карпинского [1919] обоснована взаимосвязанная система продольных (северо-западного простирания) и поперечных (северо-восточных) разрывных дислокаций по восточной периферии Фенноскандинавского щита и, в том числе, горстовое поднятие Кольского полуострова с обрамляющими его грабенами в Кандалакшском заливе и горле Белого моря, а также сбросовым уступом вдоль северо-восточного, баренцевоморского берега. Кроме этого, А.П. Карпинский наметил и северо-западное ограничение Кольского блока, указывая на поперечное направление от Мурманска к юго-западу, в сторону Ботнического залива.

Блоковое строение архейско-протерозойского фундамента, отражающее структурно-вещественные неоднородности, многократно подтверждено и проинтерпретировано с использованием как методов глубинных геофизических исследований, так и дистанционных данных [Голод, 1980; Кратц, 1978; Билибина, 1986]. Современные схемы блокового строения древнего заложения не имеют кардинальных различий, хотя роль отдельных ключевых структур, в том числе продольных и поперечных разломов, оценивается по-разному [Балуев и др., 2012; Балаганский и др. 2006; 2016], что отчетливо проявляется и при сравнении материалов разного уровня обобщения [Козлов, 1979; Горбунов, 1980; Митрофанов, 1996 (2001); Балуев, 2010].

Морфологическая выраженность блокового строения с четкими линейными границами в виде уступов или линейных грабенообразных депрессий с конца XIX стала обоснованием значительным числом исследователей признаков новейшей активизации и активных дифференцированных движений Кольского полуострова, систематически обобщавшихся в последние 50 лет [Николаев и др., 1967, Кратц и др., 1978; Стрелков и др., 1976; Легкова и др., 1977; Кошечкин, 1979; Бабак, 1980; Грачев и др., 1997; Трифонов 1987, 1999].

Как в более ранних работах, так и в последних сводках по активным разломам территории [Балуев, 2010; Бачманов и др., 2017] их локализация и иерархия существенно отличаются. По сути, позиции авторов сближаются на признании местоположения главных нарушений, определяющих границы Кольского блока и отмеченных около 100 лет назад, хотя и различаются в оценке их характера и роли в новейшей и современной тектонике региона, и существенно расходятся при рассмотрении нарушений меньшего ранга, формирующих внутреннюю блоковую структуру. Такая ситуация связана с недостаточным использованием объективных критериев, позволяющих отнести ту или иную линейную структуру к активным нарушениям.

Перечень признаков, позволяющих оценить активность тектонического нарушения, согласно сводке А.А. Никонова [1995], включает двенадцать групп (геологические, геоморфологические, вулканические, архитектурные и археологические, геодезические, ландшафтные, флюидодинамические, сейсмологические, геофизические, приземно- и собственно атмосферные и электромагнитные), подразделяемых на прямые (первые пять) и косвенные (все перечисленные, за исключением архитектурных и археологических). Из этого перечня для региональной оценки приемлемы и доступны геологические, геоморфологические, ландшафтные и сейсмологические.

Признаки активности разломов в виде позднеплейстоценовых и голоценовых деформаций рельефа и подстилающего рыхлого и коренного субстрата устанавливаются на территории Кольского полуострова уже достаточно давно [Карпов, 1960; Никонов, 1964; Буссен, 1964; Арманд и Арманд, 1966; Кошечкин, 1979, Авенариус, 1989] и по всей территории Кольского полуострова и прилегающей части северной Карелии [Николаева, 2001, 2006, 2008, 2009, 2014; 2019; Лукашов и др., 2004; Шварев, 2003; Шевченко и др., 2007; Авенариус, 2008; Верзилин, Бобков, 2008, 2009; Зыков и др., 2011; Верзилин и др., 2013; Мараханов, Романенко, 2014; Николаева и др., 2016; Никонов, Зыков, 2017]. В последнее время в связи с проведением морских сейсмоакустических работ появляются 
свидетельства активности разломов, смещающих голоценовые и позднеплейстоценовые отложения и сопровождаемые крупными гравитационными образованиями и на прилегающей к Кольскому полуострову акватории [Рыбалко и др.,2013; Шипилов и др., 2017]. Очевидно, что именно в пределах акваторий, окружающих Кольский полуостров, находятся наиболее активные структуры, сеть которых морфологически существенно выразительнее, чем на окружающей суше [Никонов и др., 2015; Шварев и др., 2015; Шварев, Никонов, 2018].

На сопредельных с Кольским полуостровом территориях северо-западной Фенноскандии детально и комплексно исследованы разломы, протяженностью до первых сотен км и обладающие всеми признаками активности - современной сейсмичностью, постледниковыми деформациями в рельефе и рыхлых отложениях, проявлениями экзогенных процессов, повторными событиями [Kujansuu, 1964; Lundkvist, Lagerbäck, 1976; Bungum, Lindholm, 1997; Dehls et al., 2000; Olesen et al., 2004; Lagerbäck, Sundh, 2008; Ojala et al., 2019; Mattila et al., 2019 и др.].

Для территории Кольского полуострова комплексные детальные исследования, позволяющие оценить активность тектонических структур по нескольким критериям с установлением параметров генерируемых землетрясений пока единичны [Николаева и др., 2016]. По большей части имеющиеся работы оценивают активность разломов по отдельным параметрам: структурно-геологическим [Колодяжный и др., 2019], морфологическим [Лукашов, Романенко, 2010; Митяев, 2014; Зыков, 2015], сейсмологическим [Никонов, Шварев, 2015].

Сложившаяся ситуация определяет актуальность поставленной цели - выявления новейшей блоковой структуры Кольского полуострова и её активизированных элементов на основе регионального сопоставления морфологических, сейсмологических, структурно-геологических, экзодинамических критериев.

\section{МЕТОДИКА И МАТЕРИАЛЫ}

Для выполнения поставленной цели необходимо решить двуединую задачу, решение которой распадается на два основных этапа исследования: 1) выявление новейшей иерархической блоково-разломной структуры; 2) установление её активизированных элементов.

Выделение новейшей блоково-разломной структуры. Основными пространственными параметрами при выделении разломно-блоковой структуры являются протяженность, простирание и глубина заложения, на основе которых определяется иерархия, степень раздробленности, системные взаимоотношения и др.

Принципиальной основой концепции блоковой делимости являются представления о дискретной структурированности литосферы в виде жестких блоков, окруженных зонами пониженной вязкости (зонами дробления) [Красный, 1984; Садовский и др., 1987]. Новейшие блоки разделяются разломными (в широком тектонофизическом понимании) зонами - разломами с оперением, совокупные подвижки по которым составляют смещение по зоне в целом [Шерман и др., 1991; Семинский, 2008], а поперечные размеры в континентальных условиях деформации значимы по отношению к смежным блокам [Семинский, 2001] и внутренняя структура которых может находиться на разных стадиях развития [Семинский, 2003].

При оценке разломно-блоковой делимости важным параметром является глубина проникновения разломов и заложения блоков, определяющих раздробленность на разных уровнях земной коры. Для оценки этих параметров использованы статистически обоснованные эмпирические соотношения:

1) для разломов длиной до 40 км: $H=1.04 L-0.7$ [Шерман, 2009]; 2) для разломов длиной более 40 км: $H=2.8 L^{0.7}$ [Саньков, 1989]; где $\mathrm{H}$ - средняя глубина проникновения разлома, Kм; L - средняя длина разлома. 
Картографические модели для анализа разломно-блоковой структуры созданы в масштабе 1:500000. Методика выделения морфологически выраженной блоковоразломной структуры опирается на совместное использование дистанционных данных среднего пространственного разрешения (15-30 м), полученных с космического аппарата Landsat-ETM+ [http://glcf.umiacs.umd.edu] за период 1999-2004 гг. и глобальной 30секундной цифровой модели рельефа GTOPO-30 с горизонтальным разрешением около 1 км и вертикальной точностью +/-30 м [https:/www.usgs.gov/centers/eros/science/usgs-erosarchive-digital-elevation-global-30-arc-second-elevation-gtopo30]. Это обеспечивает нижнюю границу выделения элементарных разрывов протяженностью $\approx 1$ км при выраженности структуры в рельефе по вертикали не менее первых десятков метров. Совмещение топографических и дистанционных данных позволяет дополнить морфологическую составляющую в индикации нарушений ландшафтной при использовании различных комбинаций синтеза многоканальных космических изображений и идентифицировать скрытые звенья блоково-разломной структуры.

Алгоритм выделения разломно-блоковой структуры базируется на интерактивном дешифрировании с применением последовательного изменения масштаба с рамках индуктивного (последовательное выделение элементарных - сложных структур при уменьшении масштаба дешифрируемых материалов) и дедуктивного (первичное выделение крупнейших структур с последовательным определением их составных частей с увеличением масштаба) подходов. В результате выявляются две категории морфолинеаментов в зависимости от масштаба структур. К первой категории относятся морфолинеаменты, в которых можно проследить индивидуальный разрыв с учетом развития по простиранию или вторичных поперечных смещений: а) элементарные (не нарушаемые другими - без пересечений и примыканий); б) единичные или простые (структуры с пересечениями и примыканиями, сохраняющие структурное единство по простиранию); в) сложные (с нарушением единства по простиранию - кулисообразные, эшелонированные структуры). Ко второй категории - морфолинеаментные зоны - системы, объединяющие индивидуальные разрывы. Элементарные блоки выделены по признаку ограничения элементарными разрывами (морфолинеаментами). Блоки высших порядков (составные блоки) определяются ограничениями разломов соответствующего порядка.

Еще один параметр, использованный для анализа - простирание морфолинеаментов (разломов) и ориентировка блоков. Простирание разломов оценивалось с разрешением $15^{\circ}$ на основе интерполяции точек замыкания, а блоков - по простиранию длинной оси между противоположными углами с разрешением $45^{\circ}$. Для разломов значительной кривизны и изометричных блоков ориентировка не оценивалась.

Оценка активности новейшей блоково-разломной структуры. В связи с употреблением терминов новейшая и активизированная блоковая структура следует определить, что под этим понимается в контексте работы. Поскольку активизированная блоковая структура предполагает разделение территории активными разломами, то следует обратиться к классификации этих структур. В большинстве классификаций учитывается несколько параметров разломов (направленность, амплитуда и др.), но основным критерием является период, в который произошло смещение. Диапазон оценок варьирует от голоцена [Allen, 1975] до четвертичного периода в целом [Active...,1980] и даже до плиоцена включительно [Atlas...,1989]. По мнению В.Г. Трифонова [1983; Трифонов и др., 1993] необходимым и достаточным для отнесения разлома к активным в подвижных областях является период 100 т.л., а в платформенных, слабоподвижных - 700 т.л. А.А. Никонов [1995] сокращает последнюю цифру до 400 т.л., опираясь на примерный возраст начала пасаденской фазы тектонической активизации, маркируемой низами среднего плейстоцена-поздним плейстоценом [Трифонов, Соколов, 2017].

Для районов плейстоценовых материковых оледенений устоявшимся термином является «постледниковый разлом» (postglacial fault), активизация которых связывается с послеледниковым компенсационным поднятием. Не вызывает сомнений, что 
постледниковая тектоническая активизация проявлялась в генерировании сильных землетрясений с поверхностным эффектом в виде тектонических разрывов преимущественно в позднеледниковье и раннем голоцене [Mörner, 2004]. Однако свидетельства сильных землетрясений в более позднее время обнаруживаются на всей территории Восточной Фенноскандии на основании палеосейсмологических, археологических и исторических данных [Никонов, 2013] и подтверждаются непосредственно на территории Кольского полуострова инструментально датированными сейсмогенными деформациями средне- и позднеголоценовых осадков [Николаева и др., 2017; 2020]. С другой стороны, при изучении крупных очаговых зон палеоземлетрясений на территории восточной Фенноскандии [Шварев, Родкин, 2017] очевидно, что значительная часть палеосейсмодеформаций имеет доледниковый возраст, что проявляется, прежде всего, в следах ледниковых воздействий на скальных сейсмодеформациях. Пока еще редкие инструментальные данные, характеризующие доледниковый (межледниковый) возраст сейсмодеформаций в рыхлых осадках, обосновывают такой вывод [Zaretskaya et al., 2019; Шварев и др., 2020]. Это является подтверждением и высказываемой ранее точки зрения на суперпозицию изостатических и собственно тектонических движений на территории Фенноскандии [Николаев, 1967] и триггерный эффект изостатических движений, усиливающих собственно тектоническую природу землетрясений [Никонов, 1977]. Поскольку геохронологические данные о доледниковых событиях весьма ограничены, то применение предложенных возрастных границ (400-700 т.л.н.) для идентификации разломов, проявлявших активность до последнего оледенения, не имеет достоверных оснований. Поэтому в данной работе предлагается к собственно активным отнести постледниковые разломы в расширительном понимании, включающим в период их проявления весь голоцен, что определяет временной интервал для Кольского полуострова 15.0-0 т.л.н., учитывая время дегляциации этой территории [Stroeven et.al., 2016]. Для всех прочих морфологически выраженных разломов предлагается применить термин «потенциально активные» (capable faults) используя предложение В.Г. Трифонова и др. [2002], но с другим временным интервалом, нижняя граница которого четко не фиксируется, но может быть ассоциирована с неоплейстоценом, оцениваемым как последний деформационный этап Кольского полуострова и его окружения [Колодяжный и др., 2019].

Таким образом, нарушения, образующие блоковую структуру, выраженную в современном рельефе, допустимо отнести к потенциально активным в неоплейстоцене, а саму блоково-разломную структуру к новейшей, в то время как часть межблоковых зон деструкции, для которых имеются признаки последниковой активности, отнести к собственно активным разломам.

Оценка активности разломов осуществлена на основе сопоставления новейшей блоково-разломной структуры с постледниковыми проявлениями экзо- и эндодинамики. С этой целью создана пространственная база данных, включающая: 1) индикаторы проявления ЭГП: а) прямые (обвальные шлейфы, эрозионно-селевые врезы; оползневые тела; водопады; речные пороги), характеризующие зоны развития гравитационных и эрозионных процессов; б) косвенные (вертикальные и крутые уступы; трещины-ущелья), указывающие на возможное развитие здесь, прежде всего, гравитационных процессов; 2) индикаторы сейсмичности: а) палеосейсмических проявлений по установленным в результате специальных натурных исследований деформациям в рельефе, скальном субстрате и рыхлых отложениях; г) эпицентры современных и исторических землетрясений с магнитудой (M) от 2 до 6 по данным трех каталогов (по сводным данным USGS [https://earthquake.usgs.gov/earthquakes/search/]; [https://www.seismo.helsinki.fi/EQ-search/query.php] $\quad$ на $\quad 2019-2020 \quad$ гг. Специализированного каталога землетрясений для задач общего сейсмического районирования (СК3 ОСР-2012) по состоянию на 2013 г. [http://seismosu.ifz.ru/documents/Eartquake-Catalog]. 
Следует отметить, что индикаторы ЭГП, в особенности явлений гравитационного ряда, являются и характерными признаками землетрясений в сейсмоактивных регионах. В условиях слабоактивной территории кристаллического Фенноскандинавского щита также обнаружены подобные зависимости для палеоземлетрясений [Ojala et al., 2019], поэтому региональное распределение подобных явлений, их приуроченность к межблоковым зонам является очевидным признаком их сейсмической активности.

Проявления экзо- и эндогенной активности, внесены в базу в форме индивидуальных точечных, линейных или площадных объектов на основе анализа топографических карт масштаба 1:100000, литературных данных с геоинформационной привязкой и координат по каталогам землетрясений. Для количественной оценки и пространственного сопоставления данных создана регулярная пространственная решетка 20x20 км, в границах ячеек которой по количество и линейное развитие экзо- и эндодинамических индикаторов активности нормированы по площади. Параметры ячеек визуализированы в изолиниях (ед/км $\left.{ }^{2} ; \mathrm{kM} / \mathrm{KM}^{2}\right)$ и сопоставлены с определением характерных сочетаний индикаторов активности и выделением зон сочетаний нескольких признаков. Активность разломов определена по их пространственному соответствию постледниковым экзо- и эндогенным проявлениям.

\section{РЕЗУЛЬТАТЫ РАБОТЫ}

Новейшее разломно-блоковое строение Кольского полуострова. Совместный анализ космических снимков и ЦМР среднего разрешения позволил выделить на территории Кольского полуострова сеть морфологически выраженных нарушений (рис.1a). Расчет соотношений индивидуальной протяженности элементарных, единичных и сложных морфолинеаментов (разломов) показывает во всех случаях гиперболически монотонно убывающие функции (рис.1г), свидетельствующие об отсутствии явно выраженной дискретной иерархии. Максимальная протяженность элементарных разрывов достигает 80-90 км, единичных разрывов - 120-130 км, а сложных разрывов - 330 км. Морфолинеаментные зоны развиты в диапазоне длин от 100 до 500 и более км (рис.1б). Категории элементарных и единичных разрывов отражают одномоментное разломообразование, а сложные разрывы и зоны - многоэтапное наращивание зоны деструкции как в длину, так и в ширину или смыкание нескольких зон. Исходя из этого, согласно эмпирическим закономерностям, установленным для стабильных континентальных регионов [Wells, Coppersmith, 1994] можно оценить максимальную моментную магнитуду землетрясений, свойственную новейшему этапу тектонического развития Кольского полуострова $\mathrm{M=7.5.}$

Из соотношений длины и глубины проникновения разломов [Саньков, 1989; Шерман, 1977; 2009] и установленного удельного количества разрывных нарушений на единицу площади (рис.1д) следует, что глубина проникновения разломов почти линейно нарастает с увеличением протяженности индивидуальных структур, достигая максимума $\approx 240$ км при протяженности $\approx 330$ км. Раздробленность (делимость) с глубиной убывает по экспоненте от максимума в поверхностном слое $\left(0.24 \mathrm{~km} / \mathrm{KM}^{2}\right)$ до $0.125 \mathrm{~km} / \mathrm{kM}^{2}$ на глубине $50 \mathrm{KM}, \approx 0.05 \mathrm{KM} / \mathrm{KM}^{2}(\approx 100 \mathrm{kM}), \approx 0,02 \mathrm{KM} / \mathrm{KM}^{2}(\approx 150 \mathrm{Kм})$ и менее $0.01 \mathrm{kм} / \mathrm{KM}^{2}$ на глубинах более 200 км.

Ориентировка разрывов на изучаемой территории (рис.1в) подчинена двум генеральным направлениям с максимумами $135^{\circ} / 315^{\circ}$ (С3) и 45\%/235 (CВ), образующими диагональную систему нарушений при абсолютном преобладании СЗ-направления, что свидетельствует о едином поле напряжений, под воздействием которого сформировалась обновленная морфоструктура Кольского полуострова, по-видимому, при С3 сжатии и СВ растяжении, сопровождаемом сдвигами, соответствующими генеральному направлению.

Ориентировка блоков (рис.1в) совпадает с простиранием индивидуальных разрывов, подтверждая единое поле напряжения, сформировавшее новейшую морфоструктуру. Однако пространственное распределение блоков (рис.1б) показывает 
территориальную перегруппировку элементарных блоков, объединяющихся в составные. Площадь элементарных блоков варьирует от 40-60 км² до 540-560 км² с максимальными величинами единичных блоков до $1700 \mathrm{~km}^{2}$. Соотношение количества и площади элементарных блоков аналогично соотношениям протяженности разрывов (рис.1е).

Поскольку приращение длины как индивидуальных морфолинеаментов, так и морфолинеаментных зон образует монотонный ряд (рис.1г), то их иерархия определена условно с регулярным интервалом 100 км, при котором выделено 6 градаций: < 100 км; 100-200 км; 200-300 км; 300-400 км; 400-500 км и > 500 км (рис.2а, б). На всех уровнях проявляется сочетание систем С3 (1) и СВ (2) нарушений с преобладанием 1-й, и значительно менее распространенные субмеридиональные (СС3) нарушения, которые, тем не менее, играют значительную роль в блоковой делимости на уровне нарушений 200-400 км (рис.2б-1,2).

Сопоставление морфолинеаментов с установленными по комплексу геологогеофизических признаков разломами архейско-протерозойского кристаллического фундамента и, отчасти, рифейских структур [Козлов, 1979; Митрофанов, 2001; Балуев, 2010] (рис.2в-1, 2, 3) показывает высокую степень их унаследованности ( $\approx 50 \%$ прямого пространственного соответствия) (рис.2в-4). Это свидетельствует о безусловно тектонической природе морфолинеаментов как унаследованных, так и не унаследованных (новообразованных), но связанных в единый новейший структурный парагенез.

Блоковая структура, образованная зонами деструкции протяженностью более 200 км, включает более 30 блоков (рис.2д). Большая часть из них (1, 2, 4-6, 9, 10, 12-14, 18, 19 , 24-27, 31, 32) сопоставима по размерам друг с другом и с нарушениями, определяющими делимость на этом уровне и, очевидно, определяют устойчивые, консолидированные ядра блоковой дифференциации. Другая часть имеет существенно меньшие размеры. Их структурная позиция промежуточная, границы образованы нарушениями более высоких порядков и отнесение к тому или иному соседнему блоку не имеет формальных оснований. Среди них различаются блоки, группирующиеся по линейным границам (20$23)$ и в узлах сочленений крупных блоков $(3,7,11,15-17,28,30)$.

Сопоставление новейшей блоковой структуры с тектоническими районами, выделенными на близком уровне генерализации [Балуев и др., 2012; Балаганский и др., 2016] (рис.2г) показывает сходимость в существенных чертах: Мурманский составной террейн практически совпадает с блоками 3,5,8-11, восточная часть Центрально-Кольского террейна отвечает блокам 6 и 12, Беломорский террейн в основных контурах близок сочетанию блоков 13, 15, 19-22, 24-28, 29-31, Карельский террейн совпадает с блоками 23, 24, 32, границы Лапландско-Колвицкого гранулитового пояса отчасти совпадают или обрамляются новейшими зонами деструкции, совпадают и ограничения Кольской глыбы вдоль Мурманского побережья и по Кандалакшскому грабену (в большей части степени вдоль Карельского берега). Преобладающая С3-ориентировка унаследована от древних зон консолидации и деструкции и проявляется в СЗ-простирании наиболее протяженных и широких морфолинеаментных зон (I.1-І.3) (рис.2а, б-5).

С другой стороны, очевидна и новейшая структурная перестройка, проявившаяся в развитии характерных черт, среди которых выделяются основные:

1) система CB-нарушений, рассекающих весь Кольский полуостров (IV.9, 10, 12, 19) (рис.2аЮ б-2);

2) субмеридиональная транс-Кольская зона (III.3) (рис.2а, б-3);

3) С3-простирания параллельные зоны от вершины Кандалакшского залива в развитие (пропагацию) Кандалакшского грабена к западу (V.75, 79) (рис.2a, б-2);

4) С3-зона от Ю3-фланга Хибинского массива к западу до озера Инари (II.2) (рис.2а, б-4);

Сочетание этих новейших зон деструкции определяет крупнейшие узловые сочленения блоков в районе южного замыкания котловины оз. Ловозеро и восточного замыкания котловины оз. Имандра. Возможно, постумное новейшее воздымание 
Хибинского и Ловозерского массивов [Жиров и др., 2018] не в последнюю очередь связано с их узловой морфоструктурной позицией.

Сочетание CB $(\mathrm{IV} .13,14)$ и субмеридиональных $(\mathrm{V} .18,19)$ зон в направлении от Кольского залива к Хибинскому массиву и к вершине Кандалакшского залива маркирует границу восточной (собственно полуостровной) и западной (материковой) частей Кольского полуострова. Пограничный характер субмеридиональной зоны, проявляющийся в различии рисунка морфолинеаментов, сопряжен с унаследованными право-сдвиговыми движениями по зоне V.19 [Митрофанов, 2001; Балуев, 2010].

Различия в новейшей геодинамике отчетливо проявляются в пространственном рисунке зон деструкции, отделяющих блоки по периферии Кольской глыбы:

1) крупнейшая Мурманская зона (I.1) на всем своем протяжении сопровождается продольными к её простиранию грабенами, формирующими в рельефе заливы, проливы, устьевые участки долин и связанными с растяжениями в зоне сдвига, фиксируемого геологическими методами [Балуев, 2010; Зыков, 2015];

2) блоки, расположенные по северной периферии Кольского полуострова и наследующие Мурманский составной террейн, динамически связаны с Мурманской зоной деструкции, что проявляется в развитии s-образных в плане, субмеридионального (СС3) простирания, межблоковых зонах, отражающих лево-сдвиговую кинематику по границе Мурманского террейна;

3) по восточной периферии Кольского полуострова дуговой разлом V.62 отделяет внешнюю часть (блок 18) от внутренней (блоки 12, 13);

4) по южной периферии такую же роль играет структура V.50, подставляемая разломом IV.20.

Следует отметить различия формы в плане дуговых разломов, обрамляющий Кольский полуостров вдоль СВ, В, ЮВ и Ю побережий: прогиб дуг разломов в обрамлении Мурманского (V.43) и Кандалакшского (Терского) (V.60; IV.20) берегов обращен в сторону материка, а развитых вдоль Горла Белого моря (V.62) - в сторону акватории. Связывая эти различия с новейшими тектоническими напряжениями, следует ожидать преобладание сбросовой кинематики разломов в условиях северо-восточного растяжения в первом случае и взбросо-надвиговой, характерной для северо-западной ориентировки оси сжатия - во втором. Такая картина соответствует новейшему продвижению Кольской глыбы относительно своего обрамления с северо-запада к юговостоку [Зыков и др., 2008; Колодяжный и др., 2019].

В западной части Мурманского побережья (блок 2), буферная зона по обрамлению Кольской глыбы отсутствует, появляясь только в районе п-ова Рыбачий, что подтверждает разницу геодинамических условий «материковой» и «полуостровной» частей. Для западной части (блоки 1 и 2) характерно преобладание протяженных субпараллельных CB-нарушений, определяющих развитие грабенов котловины оз Инари и Мурманского побережья. В отличие от восточной части Кольского полуострова, формирование новейшей морфоструктуры здесь происходит в условиях СЗ-растяжения.

Экзогенные процессы и сейсмичность в сопоставлении с новейшей блоковоразломной структурой. Региональные особенности распространения экзогенных геологических процессов на территории Кольского полуострова отличаются крайней неравномерностью, за исключением, пожалуй, почти повсеместных речных порогов как индикаторов невыработанного продольного профиля и продолжающейся глубинной эрозии рек.

Наибольшее развитие на Кольском полуострове получили обвалы (рис.За, в). Максимальная по площади распространения и количеству проявлений (до 0.25/км²) зона почти сплошного проявления обвалов вытянута вдоль Мурманского побережья от Варангер-фьорда до устья р. Вороньей и имеет максимальную ширину в районе Кольского залива и по долине р. Кола 80-100 км. Вторая по значимости зона концентрации обвальных явлений - горные массивы Хибин и Ловозерских тундр, где количество 
проявлений достигает 0.2 и $0.15 / \mathrm{kM}^{2}$ соответственно. Относительно высокими плотностями распространения обвалов отличаются горные массивы Келесуайв (юговосточнее Ковдора) (0.05/км²) , Монче- и Волчьих тундр, Лувеньгских тундр, участки побережий Кандалакшского залива в районе Порьей губы - п-ова Турий и Горла - Воронки Белого моря севернее устья р. Поной (до 0.025/км²), вершинной части Кандалакшского залива с развитием на юго-запад в направлении рр. Иова, Оланга и оз. Паанаярви, где наблюдается субширотно локализованная зона. Кроме основных зон распространения обвалов насчитывается еще около 15 локальных участков, сконцентрированных, преимущественно, в западной части территории и по побережью Баренцева моря (районы устья р.Варзины, п-ова Святой Нос).

Блоковые оползни (рис.За, г) выделены в определенной степени условно, по характерной форме фронтальных уступов и вероятных стенок отрыва, отраженных в изолиниях крупномасштабных топографических карт. Насчитывается 12 локальных зон, большая часть из которых (7) сосредоточена вдоль северного и восточного побережий Кольского полуострова. Здесь же наблюдается и максимальная концентрация (до 0.01/км²) на участке от м. Святой Нос до м. Городецкий. Остальные участки расположены в массивах Хибин, Сальных и Ловозерских тундр и в среднем течении р. Поной.

Врезы, связанные с эрозией временных водотоков, селевой деятельностью имеют максимальную концентрацию в пределах Хибинского массива (до 0.1/км²) (рис.За, д). В течение голоцена здесь развивались в парагенезе эрозионные, водоснежные, лавинные, оползневые (оползни-сплывы) и селевые процессы при преобладании последних [Романенко, Шиловцева, 2016]. Существенные зоны развития селей наблюдаются в массивах Волчьих, Сальных тундр, г. Нюрмтундра на водоразделе рр.Лотты и Ноты и Лувеньгских тундр $\quad\left(0.013-0.025 / \mathrm{KM}^{2}\right)$. Остальные проявления эрозионно-селевой деятельности локализованы на 10 участках преимущественно в центральной - югозападной части территории с единичным проявлением на побережье Горла Белого моря между устьями рр. Поной и Сосновка.

Единичные проявления интенсивной глубинной эрозии в виде водопадов наблюдаются практически на всей территории Кольского полуострова (рис.За, е). Аномальные зоны сосредоточения водопадов явно тяготеют к побережьям. Несколько слившихся зон локализации развиты в узкой прибрежной зоне практически вдоль всего Горла Белого моря (до 0.02/км²). Более обширные, с развитием вглубь территории зоны характерны для Мурманского побережья в районах бассейнов рр. Териберки, Харловки и Вороньей. Заметные сосредоточения водопадов на внутриматериковой части Кольского полуострова приурочены к массиву Ловозерских тунтр и водоразделу рр. Печенга и Патсойоки (г. Куорпукас) в северо-западной части территории.

Отвесные обрывы и крутые уступы (рис.За, ж), как индикаторы, с одной стороны, проявлений экзогенных процессов, а с другой - структурно-тектонических неоднородностей, распространены по всей территории с тяготением к западной части и фланговым (береговым) участкам. Характерные участки приурочены к побережью Варангер-Фьорда (0.1-0.2/км²), губы Орловка, Горла Белого моря, приустьевой части р. Варзуга, междуречья рр. Кола и Териберка, в массивах Хибин и Ловозерских тундр (0.05$\left.0.1 / \mathrm{KM}^{2}\right)$.

Такую же индикационную эндо-экзогенную роль играют и широко распротраненные на территории Кольского полуострова трещины, ущелья, рассекающие водоразделы, межгорные седловины и склоновые ступени (рис.За, 3). Для участков развития трещин-ущелий характерно тяготение к западной половине территории, центральной части и северного-северо-восточного побережья. Основными зонами сосредоточения являются Хибины $\left(0.05 / \mathrm{kм}^{2}\right)$, Ловозерские $\left(0.04 / \mathrm{kM}^{2}\right)$, Лувеньгские $(0.03 /$ $\left.\mathrm{Kм}^{2}\right)$, Волчьи тундры $\left(0.02 / \mathrm{Kм}^{2}\right)$, междуречье рр. Лотта и Нота $\left(0.03 / \mathrm{kM}^{2}\right)$, Печенга и Патсойоки $\left(0.03 / \mathrm{kм}^{2}\right)$, верховьев Ены, Гирваса и Тунтса-Йоки $\left(0.04 / \mathrm{kM}^{2}\right)$, Колы и Териберки (0.03/ км²). 
Прямыми показателями эндогенной активности Кольского полуострова являются землетрясения (рис.Зб). Самое раннее из исторически зафиксированных землетрясений произошло в 1542 г. в Кандалакшском заливе и имело магнитуду $\mathrm{M} \approx 5.0$, а самое сильное в 1627 г. с М 6.5 [Никонов, 2004] (по устному сообщению А.А. Никонова, в настоящее время оценки этих событий повышены до 5.8 и 7.5 соответственно). Пространственное распределение очагов землетрясений, произошедших здесь за прошедшие $\approx 460$ лет неравномерно (рис.3б, и). В большей степени сейсмическая активность характерна для западной и юго-западной частей территории, а на восточной половине отмечаются редкие и слабые очаги. Отмечается сплошная слабая сейсмичность юго-западной (Карельской) части территории с очагами землетрясений $\mathrm{M=4-5}$ и определенная линейность вдоль Кандалакшского залива, Мурманского побережья, вдоль долин рр. Кола, Печенга, в направлении от Ловозерских тундр к устью р. Харловка и от Хибин к Кольскому заливу.

Распределение следов палеоземлетрясений в значительной мере подобно полю очагов исторических и современных сейсмических событий: тяготение к западной половине, концентрация вдоль Мурманского побережья, Кандалакшского залива, в центральной части (район Хибинского, Ловозерского массивов, Лувеньгских тундр, по направлениям от центра к Кольскому заливу и устью р. Харловка. Есть и очевидные отличия, например, следы палеоземлетрясений на Терском берегу Белого моря и в районе Воронки севернее устья р. Поной. Следует отметить, что следы палеоземлетрясений маркируют иной энергетический уровень, нежели исторические или современные, поскольку только наиболее сильные из последних $(\mathrm{M} \geq 5)$ могли оставить следы в рельефе и субстрате, подобные первым. С другой стороны, современные землетрясения, имея явную приуроченность к межблоковым зонам деструкции «игнорируют» крупнейшие элементы блоково-разломной морфоструктуры, что может свидетельствовать о длительном периоде накопления напряжений в этих зонах [Морозов и др., 2019]. Поскольку на данный момент изученность палеоземлетрясений далеко не полная, при том, что фиксируются только наиболее выразительные проявления, преимущественно с интенсивностью $\geq 8$, есть все основания полагать, что остальная территории также подвергалась землетрясениям, но меньшей силы.

Интегральная оценка постледниковой активности разломов по совокупности эндогенных и экзогенных признаков демонстрирует следующие основные закономерности (рис.4):

1) Западная часть Кольского полуострова (по долготе Хибин) представляется более активной, чем восточная; в восточной части более активны фланговые прибрежные участки; в западной кроме северной береговой зоны активна и центральная часть;

2) Наиболее активными территориями являются: а) северное побережье Кольского полуострова (на всем протяжении от Варангер-Фьорда до устья р. Поной с крупными очагами в районах рр. Печенги, Титовки, Западной Лицы, Ура-Губы, Кольского залива и нижнего течения рр. Кола, Териберка, Воронья, п-ова Святой Нос); б) центральная часть - Хибинский массив с очагами на ЮЗ и В периферии; в) район Кандалакшского залива и его обрамления (Кандалакшские, Лувеньгские, Колвицкие тундры, Порья губа, Княжая губа и устье р. Ковда.

3) Наиболее протяженные морфолинеаменты, достигающие 100-110 км, ассоциированные с активными проявлениями экзо- и эндодинамики и которые можно отнести к сейсмогенерирующим разломам обнаруживаются вдоль Мурманского побережья; достигающие 90-100 км расположены в обрамлении Кандалакшского залива и в центральной части, в зоне сочленения Хибин и Ловозерских тундр с Кольским заливом; достигающие 50-70 км наблюдаются вдоль Горла Белого моря. Такие параметры поверхностных разрывов здесь, как и в других частях Кольского полуострова соответствуют сейсмическому потенциалу на уровне магнитуд 6.5-7.5, характерному для постледниковой-голоценовой активности. 


\section{ОБСУЖДЕНИЕ РЕЗУЛЬТАТОВ}

Полученные результаты свидетельствуют о том, что расчетные глубины, «корни» активизированных в новейшее крупнейших структур могут достигают глубин верхней мантии-астеносферы (рис.1д). Этот вывод соответствует данным о тесной корреляции геофизических аномалий в нижнем ярусе тектоносферы с поверхностной тектоникой Восточно-Европейской платформы и определяющей роли процессов в верхней мантии на тектонические движения [Коган, 1981; Шаров и др., 2007]. Наличие горизонтальных неоднородностей геофизических параметров, фиксирующихся от границы кора-мантия до глубин 200-250 км с линейными размерами от десятков-первых сотен до тысяч км свидетельствует о блоковом строении верхней мантии и твердом состоянии астеносферы [Шаров и др., 2007]. Раздробленность, связанная непосредственно с новейшей деструкцией поверхности сосредоточена, главным образом, в пределах коры (до глубин 40-45 км [Юдахин, 2002]), где сосредоточено 92\% элементарных разрывов (рис.1г). Мелкоблоковая раздробленность Фенноскандии, связываемая с постледниковой активизацией, проявляется в гравитационных аномалиях [Добрецов, Василевский, 2019]. По-видимому, есть прямое соотношение между пространственными параметрами элементарных разрывов и распределением эпицентров землетрясений по глубине, фиксируемых инструментальными методами [Юдахин, 2001]. Распределение демонстрирует резкое возрастание количества событий на глубинах от 2 до 10 км, симметричное крутое падение от 10 до 20 км и очень плавное снижение количества единичных событий, фиксируемых до глубин 55-60 км. Соотношение этих данных с аналогичным распределением элементарных разрывов (рис.1г) свидетельствует о наиболее сейсмически активных разрывах протяженностью $\approx 10$ км, создающих современный слабосейсмичный фон.

Крупнейшие активизированные нарушения обладают признаками глубинных долгоживущих швов (глубокий метаморфизм, магматические очаги), только обновленных на неотектоническом этапе. Поэтому не следует потенциальную глубинность проникновения связывать с новообразованием зон деструкции. Более вероятен вывод о заложении всей сети нарушений (или преобладающей её части) на ранних стадиях консолидации с последующей частичной активизацией, соответствующей меняющемуся полю напряжений на разных этапах развития [Munier, 1993; Munier, Talbot, 1993]. Новейшее поле напряжений Фенноскандинавского щита по измерениям в рудниках характеризуется преобладанием горизонтальной составляющей над вертикальной в 3-20 раз, причем оси главных напряжений сжатия имеют явно преобладающее СЗ-ЮВ направление [Юдахин, 2002], соответствующее ориентировке элементарных разрывов и блоков (рис.1в).

Иерархия блоков (рис.2б) на всех представленных уровнях (протяженностью от 100 км) определяется зонами деструкции мантийного заложения. Очевидно, что в условиях наследования новейшими разрывами древних зон, можно говорить о блоках не как консолидированных массивах, а о составных блоках, группировках элементарных блоков, отражающих крупные неоднородности в целом единого поля напряжения. Группировки элементарных блоков отчасти могут быть объединены зонами гравитационных аномалий, соотносимых с закономерностями оледенения и постледниковых процессов, и обладающих соответствующим рисунком с характерными изолированными центрами [Добрецов, Василевский, 2019]. Однако крупнейшие из таких зон расположены на флангах Кольского полуострова, имеют линейный характер и северо-западное простирание. Поэтому ожидаемо, что иерархия зон деструкции только отчасти соответствует уровню постледниковой активности, а модель постледниковой активизации должна рассматриваться в свете суперпозиции гляциотектонических (изостатических) и собственно тектонических движений. С другой стороны, изученность региона в части как постледниковых сейсмодислокаций, так и, в особенности, связи разломов с ледниковым и 
доледниковым рельефом и отложениями недостаточная и с большой вероятностью данные будут значительно скорректированы.

Количественная региональная оценка распределения экзогенных процессов на территории Кольского полуострова ранее не проводилась, хотя, безусловно, их роль в развитии рельефа оценивалась вполне адекватно, в том числе и во взаимосвязи с новейшей тектоникой [Легкова и др., 1977; Бабак и др., 1980]. Пространственная неравномерность отдельных типов процессов не обнаруживает корреляции с возможным влиянием климатического или литологического факторов, но тесно связана с тектоникой - прямо (соответствуя локализации разломов) или косвенно (сосредотачиваясь в пределах тектонически обусловленных форм рельефа). Следует отметить, что при весьма впечатляющих масштабах форм рельефа, образованных под воздействием таких процессов, как глубинная эрозия, обвальный снос, современный денудационный режим весьма скромен. Судя по многолетним наблюдениям, объемы материала ежегодно выносимого в устьевых частях рек Мурманского побережья крайне незначительны и не зависят от климатических показателей [Митяев, Герасимова, 2018]. Такое несоответствие свидетельствует в пользу редко-периодической экзогенной активизации как следствии тектогенной и подтверждает тесную взаимосвязь экзо- и эндогеодинамики Кольского полуострова.

\section{ВЫВОДЫ}

На основании проведенных исследований можно сделать следующие главные выводы:

Пространственные закономерности иерархической блоково-разломной новейшей структуры и сопряжение её с архейско-протерозойским структурным планом свидетельствуют о её формировании под воздействием единого поля напряжений с преобладающей С3 и второстепенной СВ компонентами со значительной долей обновления древних структур;

Постледниковые-голоценовые проявления экзо- и эндодинамический активности обнаруживают пространственную корреляцию друг с другом и с элементами блоковоразломной структуры;

Наиболее активны в постледниковье-голоцене: а) фланговые элементы Кольского полуострова - вдоль Баренцевоморского побережья, берегов Кандалакшского залива и Горла Белого моря; б) центральная (узловая) часть с Хибинским и Ловозерским массивами; в) субмеридионально (поперечно) секущие структуры, отделяющие восточную часть полуострова от западной (Хибины - Кола и Хибины - Нива).

Пространственные параметры активизированных зон свидетельствуют о максимальных магнитудах землетрясений, порождаемых этими структурами $\approx 6.5-7.5$ как в постледниковое время, так и в неоплейстоцене в целом.

\section{БЛАГОДАРНОСТИ}

Работа выполнена в рамках тем Госзаданий ИГ РАН №0148-2019-0005 и ИФЗ РАН № 0144-2019-0010. Автор благодарит д.г-м.н. А.А. Никонова за ценные замечания к рукописи.

\section{ЛИТЕРАТУРА}

1. Авенариус И.Г. Морфоструктурный анализ зоны новейших дислокаций на южном склоне Хибин // Геоморфология. 1989. № 2. С. 52-57.

2. Авенариус И.Г. Морфоструктурный анализ при изучении культурного и природного наследия Западно-Арктического региона России. М.: Paulsen, 2008. 190 с.

3. Арманд А.Д., Арманд Н.Н. Новейшие тектонические движения в Верхнепонойской депрессии // Геофизика и тектоника Кольского полуострова. М.-Л., 1966. С.86-89 
4. Бабак В.И. (ред.). Карта геоморфолого-неотектонического районирования Нечерноземной зоны РСФСР м-ба 1:1500000 / Гл.ред. В.И.Бабак - М., Мингео РСФСР МВ и ССО СССР - МГУ, 1980.- л.4

5. Балаганский В.В., Горбунов И.А., Мудрук С.В. Палеопротерозойские ЛапландскоКольский и Свекофеннский орогены (Балтийский щит) // Вестник Кольского научного центра РАН 3/2016(26). С.5-11

6. Балуев А.С. (Отв. ред.) Тектоническая карта Белого моря и прилегающих территорий. Масштаб 1:1500000. М.: ГИН РАН, 2010.

7. Балуев А.С., Журавлев В.А., Терехов Е.Н., Пржиялговский Е.С. Тектоника Белого моря и прилегающих территорий (Объяснительная записка к «Тектонической карте Белого моря и прилегающих территорий» масштаба 1:1500000). Отв. Ред М.Г. Леонов. М.: ГЕОС, 2012. 104 c.

8. Балаганский В.В., Минц М.В., Дэйли Дж.С. Палеопротерозойский Лапландско-Кольский ороген // Строение и динамика литосферы Восточной Европы: результаты исследований по программам ЕВРОПРОБЫ. М.: ГЕОКАРТ-ГЕОС, 2006. С. 142-155.

9. Балаганский, В. В. Палеопротерозойские Лапландско-Кольский и Свекофеннский орогены (Балтийский щит) / В. В. Балаганский, И. А. Горбунов, С. В. Мудрук // Вестник Кольского научного центра РАН. — 2016. — № 3(26). — С. 5-11.

10. Баранская А.В., Мазнев С.В., Романенко Ф.А., Шилова О.С. Новейшие движения земной коры Карельского берега Белого моря // Арктика и Антарктика, 2019, №2. С.16-33.

11. Бачманов Д.М., Кожурин А.И., Трифонов В.Г. База данных активных разломов Евразии // Геодинамика и тектонофизика. 2017. Т. 8. № 4. С. 711-736

12. Билибина Т.В. (Ред.) Блоковая тектоника и перспективы рудоносности северо-запада Русской платформы : Сб. науч. ст. Всесоюз. н.-и. геол. ин-т им. А. П. Карпинского; [Науч. редакторы Т. В. Билибина и др.] Л. : ВСЕГЕИ, 1986. 139 с.

13. Буссен И.В. Проявление послеледниковых дизъюнктивных дислокаций в рельефе южного склона Луяврурта // Рельеф и геологическое строение осадочного покрова Кольского полуострова. М.-Л., 1964, с.77-79

14. Верзилин Н.Н., Бобков А.А. По следам послеледниковых сейсмических проявлений в северо-восточном ограничении губы Чупа Белого моря // Геология, геоэкология, эволюционная география. Коллективная монография. Под. Ред. Е.М. Нестерова. СПб: «Эпиграф», 2008. С.37-40

15. Верзилин Н.Н., Бобков А.А. Следы голоценовых землетрясений на севере Кольского полуострова / Геология, геоэкология, эволюционная география. СПб. 2009. С. 20-25.

16. Верзилин Н.Н., Бобков А.А., Кулькова М.А., Нестеров Е.М., Нестерова Л.А., Мадянова Н.П. О возрасте и образовании современного расчлененного рельефа севера Кольского полуострова // Вестник Санкт-Петербургского университета. Серия 7: Геология. География. 2013. Т. 2. С. 79-93.

17. Голод М.И. (ред.) Геофизические исследования восточной части Балтийского щита. Петрозаводск. 1980. 184 с.

18. Горбунов Г.И. (Гл. ред.) Геологическая карта-схема Кольского полуострова. Масштаб 1:1000000. Составители В.Г. Загородный, В.И. Пожиленко, А.Т. Радченко, авторы макетов В.В. Балаганский, О.А. Беляев, М.Н. Богданова, Л.Л. Гарифугин, М.М. Ефимов, В.Г. Загородный, А.И. Ивлиев, Н.Е. Козлова, Н.А. Кравцов, И.В. Никитин, В.И. Пожиленко, А.Т. Радченко, Е.С. Степкин. Л.: ВСЕГЕИ, 1980.

19. Грачев А.Ф. (ред.). Карта новейшей тектоники Северной Евразии. Масштаб: 1:5000000. 1997 г. / ВИМС МПР России. ОИФЗ РАН. 1997 г.

20. Добрецов Н.Л., Василевский А.Н. Отражение постгляциальных поднятий в гравитационном поле и неоген-четвертичных структурах // Геология и геофизика, 2019, т.60, №12, с.1661-1691 
21. Жиров Д.В., Маринин А.В., Жирова А.М., Сим Л.А. Неотектоника южной части Хибинского массива: результаты комплексной интерпретации «необычных» явлений / Труды Ферсмановской научной сессии ГИ КНЦ РАН. Апатиты. 2018. С. 140-143.

22. Зыков Д.С. Геоморфологические признаки проявления горизонтальной компоненты неотектонических движений вдоль границы Балтийского щита и Западно-Арктической платформы (Мурманская область)// Геоморфология. 2015. №3. С.27-38

23. Зыков Д.С., Колодяжный С.Ю., Балуев А.С. Признаки горизонтальной неотектонической подвижности фундамента в районе Беломорья // Бюлл. МОИП. Отд. Геол. 2008. Т.83. вып.2. С.15-25

24. Зыков Д.С., Терехов Е.Н., Балуев А.С. Признаки новейшей активизации разрывов и следы вероятных палеосейсмодеформаций на участке Баренцевоморского побережья Кольского полуострова // Материалы Всерос. конференции «Проблемы сейсмотектоники». Москва. 2011. С. 210-214.

25. Карпов Н.Н. Следы послеледниковых тектонических разломов в Хибинских горах // Вестн. МГУ, сер.5, география, 1960, №4. С.61

26. Коган С.Д. Об особенностях строения верхней мантии // Изв. РАН. Физика Земли. 1981, №5. C.3-17

27. Козлов М.Т. Разрывная тектоника северо-восточной части Балтийского щита. Л., «Наука», 1979. 140 с.

28. Колодяжный С.Ю., Балуев А.С., Зыков Д.С. Структура и эволюция северо-запада Беломорско-Северодвинской зоны сдвига в позднем протерозое и фанерозое (ВосточноЕвропейская платформа) // Геотектоника, 2019, №1, с.62-86

29. Кошечкин Б.И. Голоценовая тектоника восточной части Балтийского щита. Л.: Наука, 1979. 158 с.

30. Красный Л.И. Глобальная делимость литосферы в свете геоблоковой концепции // Советсткая геология, 1984, №7. С.17-32.

31. Кратц К.О. (Ред.) Земная кора восточной части Балтийского щита. Л.: Наука. 1978. 230 с.

32. Легкова В.Г., Бонбенков В.Н., Щукин Л.А., Можаева В.Г., Млжаев Б.Н. Матвеева Г.В., Соколова В.Б., Сипакова М.С., Симоненко Т.Н. Геоморфология Карелии и Кольского полуострова. Л.: Недра, 1977. 183 с.

33. Лукашов А.А., Кузнецов Д.Е., Романенко Ф.А. Геоморфологические признаки позднеголоценовой сейсмической активности восточной части Хибинского массива (Кольский полуостров) // Геодинамика и геологические изменения в окружающей среде северных регионов. 2004. Т. II. С. 25-29.

34. Лукашов А.А., Романенко Ф.А. Характер и морфодинамика дизъюнктивного северовосточного ограничения Балтийского щита («линии Карпинского») // Тектоника и геодинамика складчатых поясов и платформ фанерозоя. Материалы XLIIIтектонического совещания. Т.1. М.: ГЕОС, 2010. С.430-434

35. Лукашов А.Д. Геодинамика новейшего времени // Глубинное строение и сейсмичность Карельского региона и его обрамления. Под ред. Н.В. Шарова. Петрозаводск, КарНЦ РАН, 2004. C.150-191

36. Мараханов А.В., Романенко Ф.А. Новые данные о послеледниковых сейсмодислокациях Северной Карелии (Карельский берег Белого моря) // Юдахинские чтения. Геодинамика и геоэкология Баренц-региона в XXI веке: М-лы докл. Всеросс. конф. с междунар. участием (15-18 сент. 2014 года). - Архангельск, 2014. С.137-140

37. Митрофанов Ф.П. (Гл. ред.) Геологическая карта Кольского региона масштаба 1:500000. Ред. А.П. Радченко (Россия), К. Гиллен (Великобритания). Авторы-составители В.В. Балаганский, А.А. Басалаев, О.А. Беляев, В.И. Пожиленко, А.Т. Радченко, М.К. Радченко. Апатиты, 1996. Испр. и дополн. В.И. Пожиленко, 2001

38. Митяев М.В. Мурманское побережье (геолого-геоморфологические и климатические особенности, современные геологические процессы). Апатиты: Изд. КНЦ РАН, 2014. 226 c. 
39. Митяев М.В., Герасимова М.В. Сток воды, взвешенных веществ и интенсивность эрозии на Мурманском побережье // Известия РАН. Серия географическая, 2018, №1, с.111-128

40. Николаев Н.И., Бабак В.И., Медянцев А.И. Вопросы неотектоники Балтийского щита и норвежских каледонид // Советская геология. 1967. №3, с. 3-23

41. Николаева С.Б. Палеосейсмические проявления в северо-восточной части Балтийского щита и их геолого-тектоническая позиция // Геоморфология. 2001. № 4. С. 66.

42. Николаева С.Б. Сейсмогенные деформации в отложениях раннеголоценовой террасы реки Печенга (Кольский полуостров)// ДАН. 2006.Т.406. №1. С.69-72

43. Николаева С.Б. Следы разрушительных землетрясений в окрестностях города Мурманска (по историческим и палеосейсмологическим данным) // Вулканология и сейсмология. 2008, №3, с.52-61

44. Николаева С.Б. Сейсмиты в позднеплейстоцен-голоценовых осадках северо-запада Кольского региона (северная часть Балтийского щита) // Геология и геофизика, 2009, т.50, №7, c.830-839

45. Николаева С.Б. Складчатые деформации в позднеплейстоценовых отложениях Хибин (центральная часть Кольского полуострова): морфология и генезис// Вестник МГТУ, 2014, том 17, №2, с.329-339

46. Николаева С.Б. Послеледниковая тектоника и палеосейсмодислокации в районе участка Ковды (Кандалакшский залив Белого моря) // Вестник Санкт-Петербургского университета. Науки о Земле. 2019, Т.64, №3, стр.434-453

47. Николаева С.Б., Никонов А.А., Шварев С.В., Родкин М.В. Комплексные палеосейсмогеологические исследования на ключевом участке в юго-западной части Кольского полуострова (северо-восток Фенноскандинавского щита) // Доклады академии наук, 2016, том 469, №2, с.199-203

48. Николаева С.Б., Лаврова Н.Б., Денисов Д.Б. Катастрофическое событие голоцена в донных осадках озер Кольского полуострова (СВ Фенноскандинавского щита) // ДАН. 2017. Т. 473. № 1. С. 88-92.

49. Николаева С.Б. Евзеров В.Я. К геодинамике Кольского региона в позднем плейстоцене и голоцене: обзор и результаты исследований // Вестник ВГУ. Серия: Геология. 2018. №1. C.5-14

50. Николаева С. Б., Шварев С. В., Родкин М. В., Королева А. О. Шонгуйские дислокации в структуре основных сейсмогенных зон Кольского региона: проявления, тектоническая позиция, возраст // Труды Ферсмановской научной сессии ГИ КНЦ РАН. — Т. 17. — Апатиты, 2020. - С. 390-394.

51. Никонов А.А. Геоморфологические признаки позднечетвертичных движений земной коры на западе Кольского полуострова // Четвертичные и грунтовые воды Кольского полуострова. Л.: 1964. С.96-105

52. Никонов А.А. Голоценовые и современные движения земной коры (геологогеоморфологические и сейсмотектонические вопросы). М.: Наука, 1977. 240 с.

53. Никонов А.А. Активные разломы: определение и проблемы выделения // Геоэкология. Инженерная геология. Гидрогеология. Геокриология. 1995, №4. С.16-27

54. Никонов А.А. Исторические землетрясения // Глубинное строение и сейсмичность Карельского региона и его обрамления / Под ред. Н.В. Шарова. Петрозаводск: Карельский научный центр РАН, 2004. С. 192-213.

55. Никонов А.А. Новый этап познания сейсмичности Восточно-Европейской платформы и её обрамления // Доклады академии наук, 2013, том 450, №4, с.465-469

56. Никонов А.А., Зыков Д.С. О признаках мощных землетрясений в восточном секторе Мурманской зоны (линия Карпинского) // Труды Ферсмановской научной сессии ГИ КНЦ PAH. 2017. №14. С.143-148

57. Никонов А.А., Шварев С.В. Сейсмолинеаменты и разрушительные землетрясения в российской части Балтийского щита: новые решения для последних 13 тысяч лет // 
Материалы Международной конференции «Геолого-геофизическая среда и разнообразные проявления сейсмичности». - Нерюнгри: Изд-во Техн. Ин-та (ф) СВФУ, 2015. С.243-251.

58. Никонов А. А., Шварев С. В., Николаева С. Б. Мурманское побережье - крупнейшая а Российской Арктике сейсмогенерирующая зона: новейшие разработки // Материалы международной научной конференции Природные ресурсы и комплексное освоение прибрежных районов Арктической зоны: Сб. научных трудов / Отв. ред. Д.э.н., проф. В.И. Павленко. - Архангельск, 2015. - С. 34-40.

59. Романенко Ф.А., Шиловцева О.А. Геоморфологические процессы в горах Кольского полуострова и изменения климата // Вестн. Моск. ун-та. Сер.5. География. 2016. №6. С.7886

60. Рыбалко А. Е., Федорова Н. К., Никитин М. А., Токарев М. Ю. Геодинамические процессы в Кандалакшском заливе Белого моря и их роль в формировании покрова современных осадков // Матер. XX Межд. научн. конфер. (школы) по морской геологии. М., 2013. Т. III. С. 237-241.

61. Садовский М.А., Болховитинов Л.Г., Писаренко В.Ф. Деформирование геофизической среды и сейсмический процесс. М.: Наука, 1987. 100 с.

62. Саньков В.А. Глубины проникновения разломов. Новосибирск: Наука. Сибирское отд., 1989. 136 с.

63. Семинский К.Ж. Тектонофизические закономерности деструкции литосферы на примере Гималайской зоны сжатия // Тихоокеанская геология, 2001, т.20, №6. С.17-30

64. Семинский К.Ж. Иерархия зонно-блоковой структуры литосферы Центральной и Восточной Азии // Геология и геофизика, 2008, т.49, №10, с.1018-1030

65. Семинский К.Ж. Внутренняя структура континентальных разломных зон. Тектонофизический аспект. Новосибирск, Изд-во СО РАН, филиал «Гео», 2003. 243 с.

66. Стрелков С.А., Евзеров В.Я., Кошечкин Б.И., Рубинраут Г.С., Афанасьев А.П., Лебедева Р.М., Каган Л.Я. История формирования рельефа и рыхлых отложений северо-восточной части Балтийского щита. Л.: Наука, 1976. 164 с.

67. Трифонов В.Г. (ред.) Карта активных разломов СССР и сопредельных территорий. М-б 1:8 млн. Объяснит. Записка / Под редакцией В.Г.Трифонова. М.:ГИН, 1987. 48 с.

68. Трифонов В.Г. Неотектоника Евразии. М.: Научный мир, 1999 - 243 с.

69. Трифонов В.Г. Позднечетвертичный тектогенез. М.: Наука, 1983. 224 с.

70. Трифонов В.Г., Кожурин А.И., Лукина Н.В. Изучение и картирования активных разломов // Сейсмичность и сейсмическое районирование Северной Евразии. Вып. 1. М.: ИФ3, 1993. С.196-205

71. Трифонов В.Г., Соболева О.В., Трифонов Р.В., Востриков Г.А. Современная геодинамика Альпийско-Гималайского коллизионного пояса. М.: ГЕОС, 2002. 225 с. (Тр. ГИН РАН; вып.541)

72. Трифонов В.Г., Соколов С.Ю. Сопоставление тектонических фаз и инверсий магнитного поля в позднем мезозое и кайнозое // Вестник Российской академии наук, 2017, том 87, №12. С.1091-1097

73. Шаров Н.В., Маловичко А.А., Щукин Ю.К. (ред.) Землетрясения и микросейсмичность в задачах современной геодинамики Восточно-Европейской платформы. Кн. 1 : Землетрясения. Петрозаводск: Карельский научный центр РАН, 2007. 381 с.

74. Шварев С.В. Послеледниковые тектонические движения и формирование террас оз. Имандра (Кольский полуостров) // Геоморфология. 2003. № 4. С. 97-105

75. Шварев С. В., Никонов А. А., Фроль В. В. Морфоструктура, тектоническая и сейсмическая активность в бассейне Белого моря: анализ на основе ЦМР, геологических и сейсмических данных // Геоморфологические ресурсы и геоморфологическая безопасность: от теории к практике: Всероссийская конференция VII Щукинские чтения. - МАКС Пресс Москва, 2015. - C. 199-202.

76. Шварев С. В., Никонов А. А. Морфотектоника бассейна Белого моря в сопоставлении с уточненными характеристиками исторических землетрясений // Материалы 
Всероссийской научной конференции «Поздне- и постгляциальная история Белого моря: геология, тектоника, седиментационные обстановки, хронология»: сборник статей. КДУ, Университетская книга Москва, 2018. - С. 174-180.

77. Шварев С. В., Родкин М. В. Структурная позиция и параметры палеоземлетрясений в районе горы Воттоваара (Средняя Карелия, восточная часть Фенноскандинавского щита) // Вопросы инженерной сейсмологии. - 2017. - Т. 44, № 2. - С. 35-60.Шевченко Н.В., Кузнецов Д.Е., Ермолов А.А. Сейсмотектонические проявления в рельефе берегов Белого моря // Вестник Моск. Ун-та. Сер. География. 2007. № 3. С. 44-48.

78. Шварев С. В., Субетто Д. А., Зарецкая Н. Е., Молодьков А. Н. Возраст, генезис и сейсмогенные деформации террас реки Вуокса на Карельском перешейке, северо-запад России // Геология и геофизика. - 2020 (в печати).

79. Шерман С.И. Физические закономерности развития разломов земной коры. Новосибирск: Наука СО РАН, 1977. 103 с.

80. Шерман С.И. Тектонофизические параметры разломов литосферы, избранные методы изучения и примеры использования // Современная тектонофизика. Методы и результаты. М.: ОИФЗ РАН, 2009. С.302-317

81. Шерман С.И., Семинский К.Ж., Борняков С.А., Буддо В.Ю., Лобацкая Р.М., Адамович А.Н., Трусков В.А., Бабичев А.А. Разломообразование в литосфере. Зоны сдвига. Новосибирск: Наука, 1991. 262 с.

82. Шипилов Э.В., Шкарубо С.И., Ковальчук Е.А. Структура и литологический состав отложений Кольского залива (фьорда) по данным бурения и сейсмоакустики и неотектонические условия его формирования // Арктика: экология и экономика. 2017. №4 (28). С.72-82

83. Юдахин Ф.Н. (ред.) Литосфера и гидросфера европейского Севера России. Геоэкологические проблемы. Екатеринбург: Изд. УрО РАН, 2001. 408 с.

84. Юдахин Ф.Н. Геодинамические процессы в земной коре и сейсмичность континентальной части Европейского Севера // Литосфера, 2002, №2. С.3-23.

85. Active faults in and around Japan: the distribution and the degree of activity // J. Natur. Disas. Sci. 1980. V.2. No.2. P.61-99

86. Allen C.R. Geological criteria for evaluating seismicity // Bul. Geol. Soc. Amer. 1975. Vol.86, N8. P.1041-1057

87. Atlas of active faults in China. Editor-in-Chief Ding Guoyu // Seismol. Press. 1989. 123 p.

88. Kujansuu R. Nuorista sirroksista Lapissa. Summary: recent faults in Lapland. Geologi 16, 30-36

89. Bungum H., Lindholm C. Seismo- and neotectonics in Finnmark, Kola Peninsula and the southern Barents Sea. Part 2: Seismological analysis and seismotectonics. Tectonophysics 270, 15-28

90. Dehls J.F., Olesen O., Olsen L., Blikra L.H. Neotectonic faulting in northern Norway; the Stuoragurra and Nordmannvikdalen postglacial faults // Quaternary Science Reviews 19 (2000) 1447-1460

91. http://glcf.umiacs.umd.edu

92. https://www.usgs.gov/centers/eros/science/usgs-eros-archive-digital-elevation-global-30-arcsecond-elevation-gtopo30?qt-science_center_objects=0\#qt-science_center_objects

93. https://earthquake.usgs.gov/earthquakes/search/

94. https://www.seismo.helsinki.fi/EQ-search/query.php

95. http://seismos-u.ifz.ru/documents/Eartquake-Catalog-\%D0\%A1\%D0\%9A\%D0\%97.pdf

96. Lagerbäck R., Sundh M. Early Holocene faulting and paleoseismicity in northern Sweden: Research Paper C 836. Geological Survey of Sweden

97. Lundqvist J., Lagerbäck R. The Pärve Fault: a late-glacial fault in the Precambrian of Swedish Lapland. 1976. Geol. Foren. Stockh. Forh. 98, 51-54

98. Mattila J., Ojala A.E.K., Ruskeeniemi T., Palmu L-P., Aaltonen I., Käpyano A., Lindberg A., Sutinen R. Evidence of multiple slip events on postglacial faults in northern Fennoscandia // Quaternary Science Reviews, 2019. 215:242-252 
99. Mörner N-A. Active faults and paleoseismicity in Fennoscandis, especially Sweden. Primary structures and secondary effects // Tectonophysics 380 (2004) 139-157

100. Munier R. Segmentation, fragmentation and jostling of the Baltic shield with time // Acta Univ. Upsal. Upsala Diss. Fac. Sci. No 37. 1993. P.1-96.

101. Munier R., Talbot C.J. Segmentation, fragmentation and jostling of cratonic basement in and near Äspö, Southeast Sweden // Tectonics, 1993, vol.12, No.3, pp.713-727

102. Ojala A.E.K., Mattila J., Ruskeeniemi T., Markovaara-Koivisto M., Palmu J-P., Nordback N., Lindberg A., Sutinen R., Aaltonen I., Savinen J. Postglacial faults in Finland - a review of PGSdin project results. POSIVA OY, Olklluoto, FI-27160 EURAJOKI, Finland, April 2019. ISBN 978-951-652-271-8, ISSN 2343-4740

103. Ojala A.E.K., Mattila J., Markovaara-Koivisto M., Ruskeeniemi T., Palmu J-P., Sutinen R. Distribution and morphology of landslides in northern Finland: An analysis of postglacial seismic activity January 2019 Geomorphology 326:190-201 DOI: 10.1016/j.geomorph.2017.08.045

104. Olesen O., Blikra L.H., Braathen A., Dehls J.F., Olsen L., Rise L., Roberts D., Riis F., Faleide J.I., Anda E., Neotectonic deformation in Norway and its implications: a review // Norwegian Journal of Geology, 84, 3-34. ISSN 029-196X

105. Stroeven A. P., Hättestrand C., Kleman J., Heyman J., Fabel D., Fredin O., Goodfellow B. W., Harbor J. M., Jansen J. D., Olsen L., Caffee M. W., Fink D., Lundqvist J., Rosqvist G. C., Strömberg B., Jansson K. N. Deglaciation of Fennoscandia // Quaternary Science Reviews. 2016. Vol. 147. P 91-121.

106. Wells D.L., Coppersmith K.J. New Empirical Relationships among Magnitude, Rupture Length, Rupture Width, Rupture Area, and Surface Displacement // Bulletin of the Seismological Society of America, Vol.84, No.4, pp. 974-1002, August 1994

107. Zaretskaya N., Shvarev S., Korsakova O., Grigoriev V. Palaeoseismic traces in the Late Pleistocene deposits of Southern Kola Peninsula // Börner, A., Hüneke, H., Lorenz, S., (Eds.), Field Symposium of the INQUA PeriBaltic Working Group "From Weichselian Ice-Sheet Dynamics to Holocene Land Use Development in Western Pomerania and Mecklenburg”. Abstract Volume. Scientific Technical Report STR 19/01, Potsdam: GFZ German Research Centre for Geosciences. 2019. Pp.131-133. 


\section{ПЕРЕЧЕНЬ РИСУНКОВ:}

Рис. 1 Элементарные разломы и морфотектонические блоки Кольского полуострова: а) элементарные морфолинеаменты по материалам интерпретации дистанционных данных среднего разрешения: космических снимков Landsat-ETM+ и цифровой модели рельефа GTOPO-30; б) элементарная блоковая структура и ориентировка блоков: 1- блокоразделы; ориентировка длинных осей блоков: 2 - субмеридиональная; 3 - СВ-Ю3; 4 - субширотная; 5 - СЗ-ЮВ; 6 - неопределенная; в) распределение направлений разрывов и ориентировки длинных осей блоков; г) распределение количества разломов в зависимости от протяженности; д) глубина проникновения разломов и раздробленность на разных глубинах в зависимости от количества разломов различной протяженности; е) распределение количества элементарных блоков в зависимости от площади.

Рис. 2 Иерархия и унаследованность морфологически выраженной блоковой структуры: а) сводная схема морфологически выраженных разломов различной протяженности и блоков, выделенных на уровне делимости территории разломами протяженностью более 200 км; б) делимость территории зонами деструкции на иерархических уровнях по протяженности (сверху вниз): 100-200 км; 200-300 км; 300-400 км; 400-500 км; более 500 км; в) разломы в кристаллическом фундаменте, выделенные геологическими и геофизическими методами (слева направо) по М.Т. Козлову (1979); по Ф.П. Митрофанову (2001); по А.С. Балуеву (2010); унаследованность новейшими разломами архейско-протерозойской разломной структуры; г) сводная тектоническая схема (по Балаганскому и др., [2016] и Балуеву и др., [2012]); д) новейшая блоковая структура на уровне делимости разломами протяженностью более 200 км. Условные обозначения: иерархическое разломно-блоковое строение по морфологическим данным (схемы а, б, д), морфолинеаменты протяженностью: 1 - более 500 км (І порядка); 2 - 400-500 км (II порядка; 3 - 300-400 км (III порядка); 4 - 200-300 км (IV порядка); 5 - 100-200 км (V порядка); 6 - менее 100 км; 7 - блоковая структура на уровне делимости IV и более низких порядков; тектоническое районирование и разломы (схемы в, г): Восточно-Европейский кратон, Балтийский щит: 8 - Мурманский составной террейн; 9 - Центрально-Кольский составной террейн; 10 - Карельский составной террейн; 11 - Беломорский составной террейн (А - Стрельнинский террейн; Б - террейн Инари); 12 - Терский террейн; 13 - Лапландско-Ковицкий гранулитовый пояс; 14 палеопротерозойский рифт (А - Имандра-Варзугская зона; Б - Печенгская зона); 15 плитная часть Восточно-Европейского кратона (Мезенская синеклиза): 16 - рифтогенные грабены (А - Онежско-Кандалакшский; Б - Керецко-Пинежский; В - Мезенский); 17 Тимано-Печорская плита; 18 - складчатые рифейско-вендские образования; 19 Свальбардская плита; 20 - проявления среднепалеозойского магматизма (массивы ультраосновного-щелочного комплекса; 21 - конвергентная граница литосферных плит; разломы: 22 - границы составных террейнов; 23 - граница орогенного ядра; 24 - взбросы и надвиги; 25 - сбросы; 26 - прочие крупные разломы.

Рис. 3 Проявления ЭГП и сейсмичность: а) основные зоны распространения ЭГП; б) современная и палеосейсмичность; пораженность территории (количество проявлений/400 км$^{2}$ ): современными проявлениями ЭГП - в) обвалы; г) сели и временные водотоки; д) блоковые оползни; е) речная эрозия (водопады); вероятными проявлениями ЭГП и высокоградиентные формы рельефа (вероятные зоны проявления активной тектоники и тектогенного морфогенеза - ж) крутые уступы и вертикальные стенки; з) открытые трещины-ущелья; и) интенсивность современных и исторических землетрясений (по сводным данным USGS; FENCAT на 2019-2020 гг. и Специализированного каталога землетрясений для задач общего сейсмического районирования (СКЗ ОСР-2012) по состоянию на 2013 г.). Условные обозначения к схемам а и б: проявления и индикаторы ЭГП: 1 - обвалы; 2 - блоковые оползни; 3 - водопады; 4 - сели и крупные овражные 
врезы; 5 - трещины; 6 - крутые уступы; 7 - скальные стенки; эпицентры землетрясений по инструментальным и историческим данным с магнитудой (М): 8 - 1-2; 9 - 2-3; 10 - 3-4; 11 - 4-5; 12 - 5-6; места обнаружения палеосейсмодеформаций: 13 - документированные по [Николаева, 2001, 2006, 2008, 2009, 2014; 2019; Лукашов и др., 2004; Шварев, 2003; Шевченко и др., 2007; Авенариус, 2008; Верзилин, Бобков, 2008, 2009; Зыков и др., 2011; Верзилин и др., 2013; Мараханов, Романенко, 2014; Николаева и др., 2016; Никонов, Зыков, 2017; Баранская и др., 2019]; 14 - предполагаемые зоны массового развития: а - по С.Б. Николаевой и В.Я. Евзерову [2018]; б - по А.Д. Лукашову [2004]

Рис. 4 Активизированные элементы блоково-разрывной структуры по экзо- и эндогенным признакам. Условные обозначения: признаки активизации - зоны распространения: 1 экзогенных процессов; 2 - тектонических форм рельефа; 3 - палеосейсмодеформаций (палеоземлетрясений); 4 - современных и исторических землетрясений; зоны сочетания признаков: 5 - двух; 6 - трёх; 7 - четырех; морфолинеаменты - предполагаемые активизированные элементы блоково-разрывной структуры по контролируемым ими зонам: 8 - развития ЭГП; 9 - сейсмогенных форм рельефа; 10 - палеосейсмодеформаций; 11 - очагов современных и исторических землетрясений. 

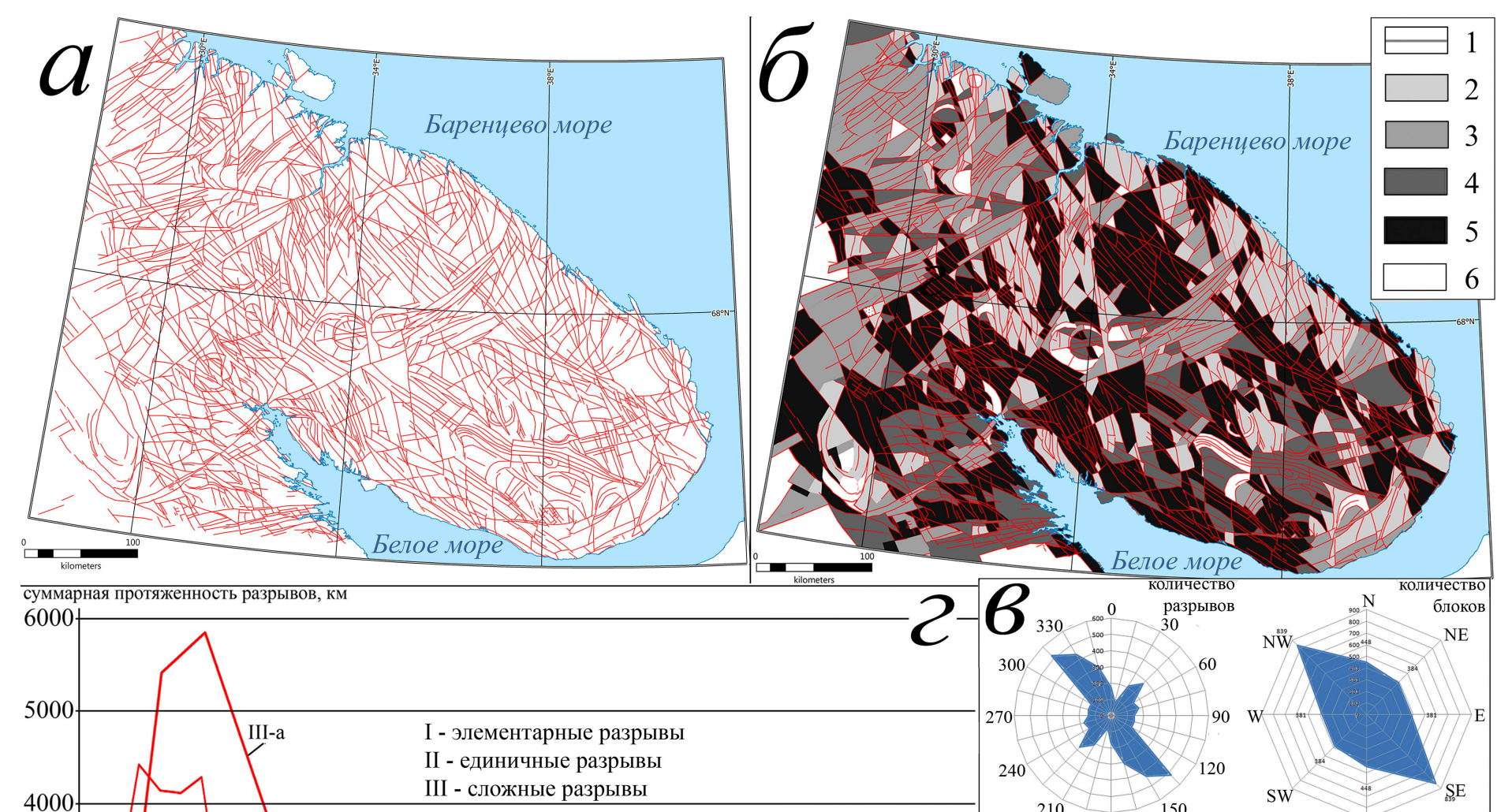

а - суммарная протяженность, км
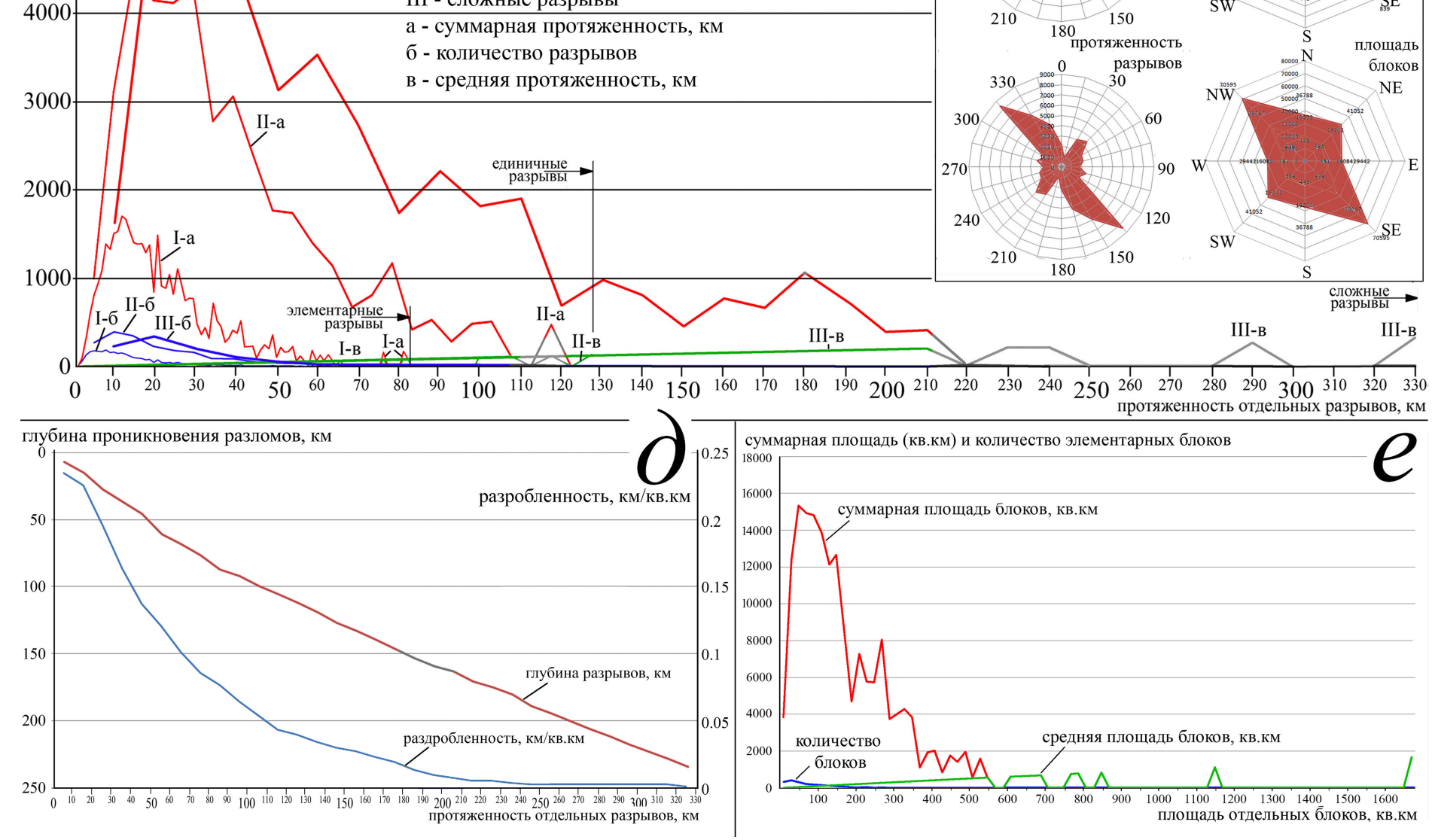


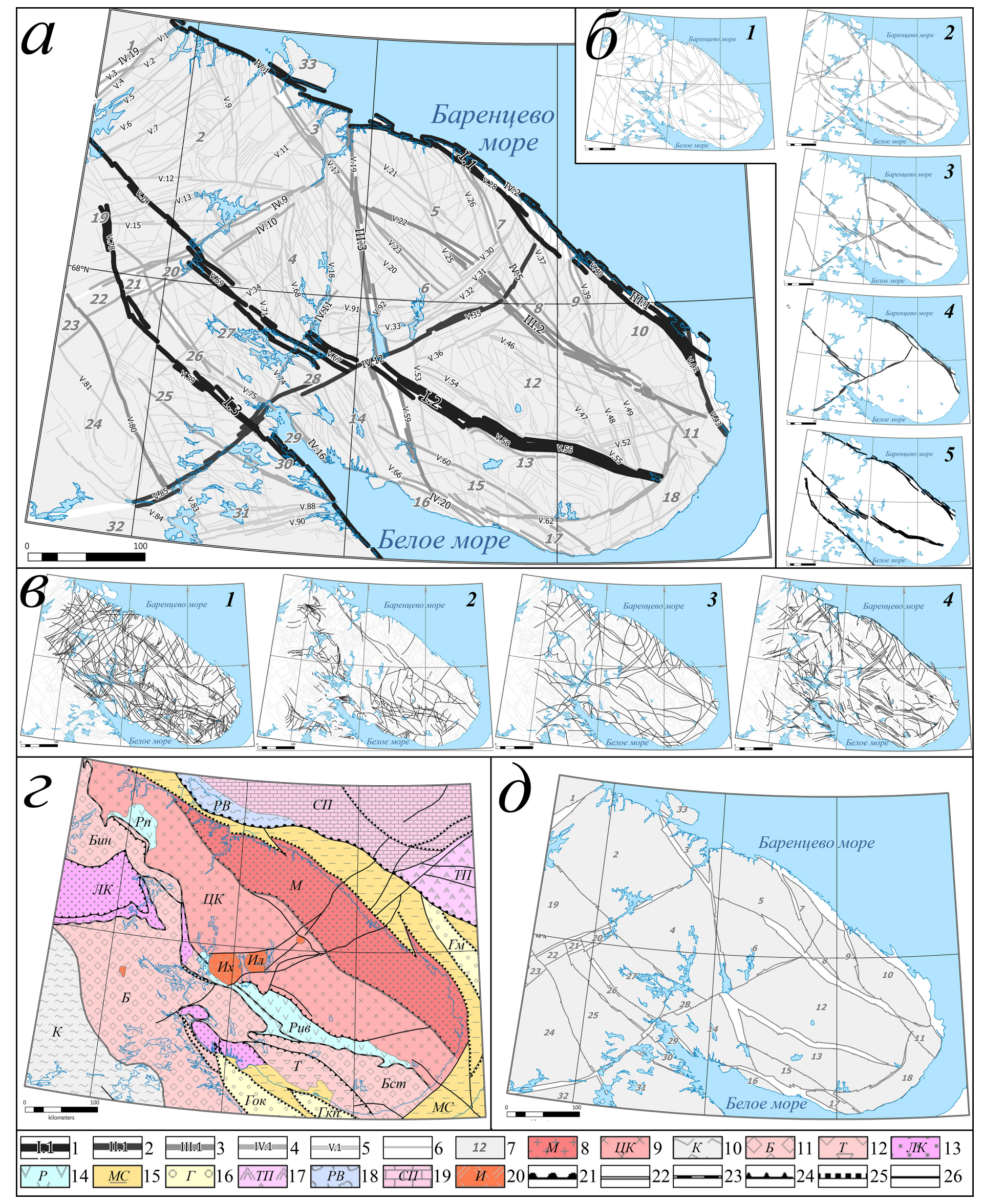



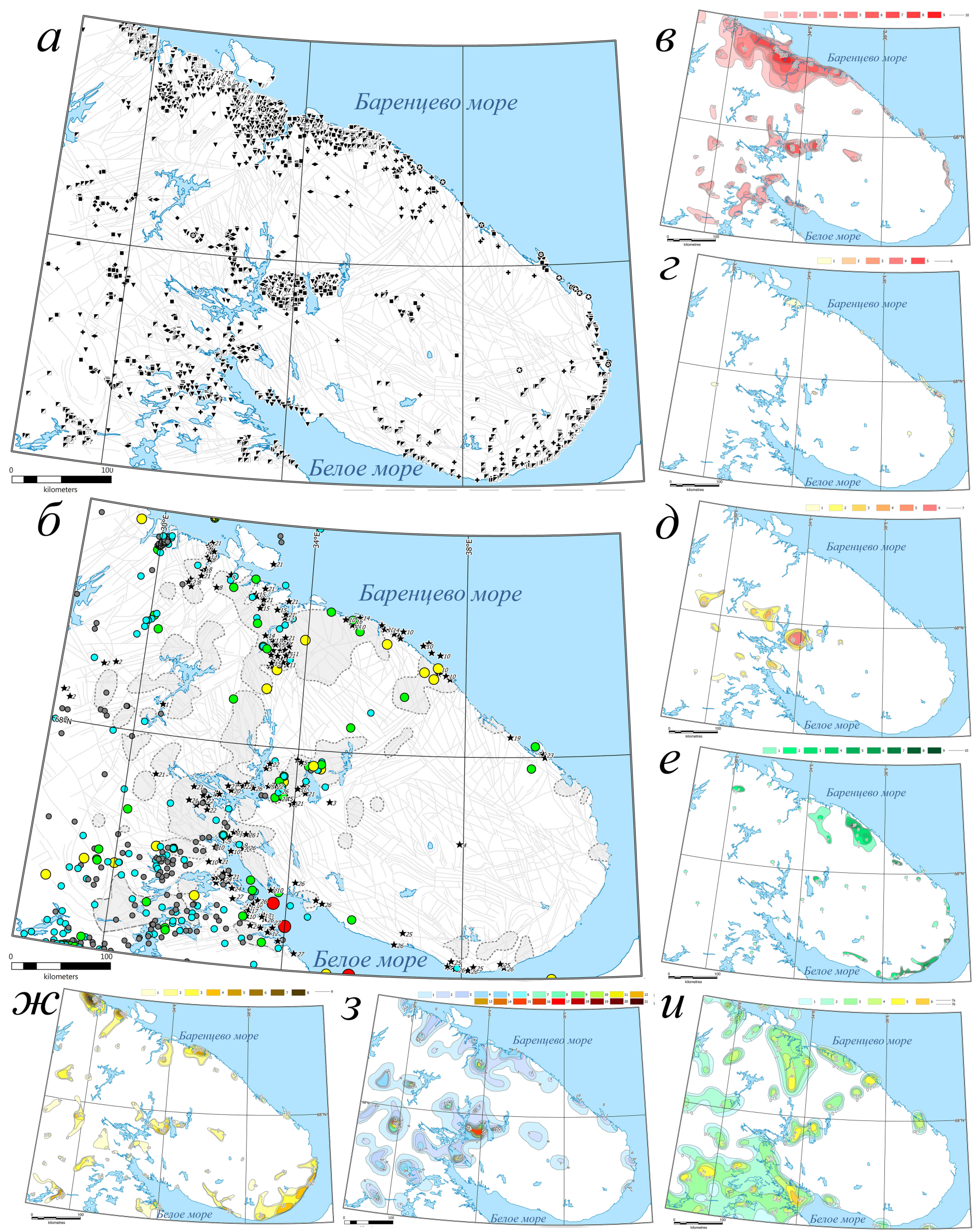

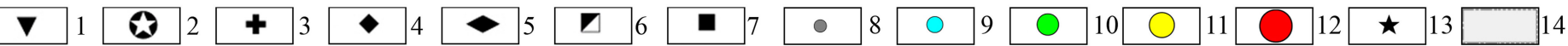




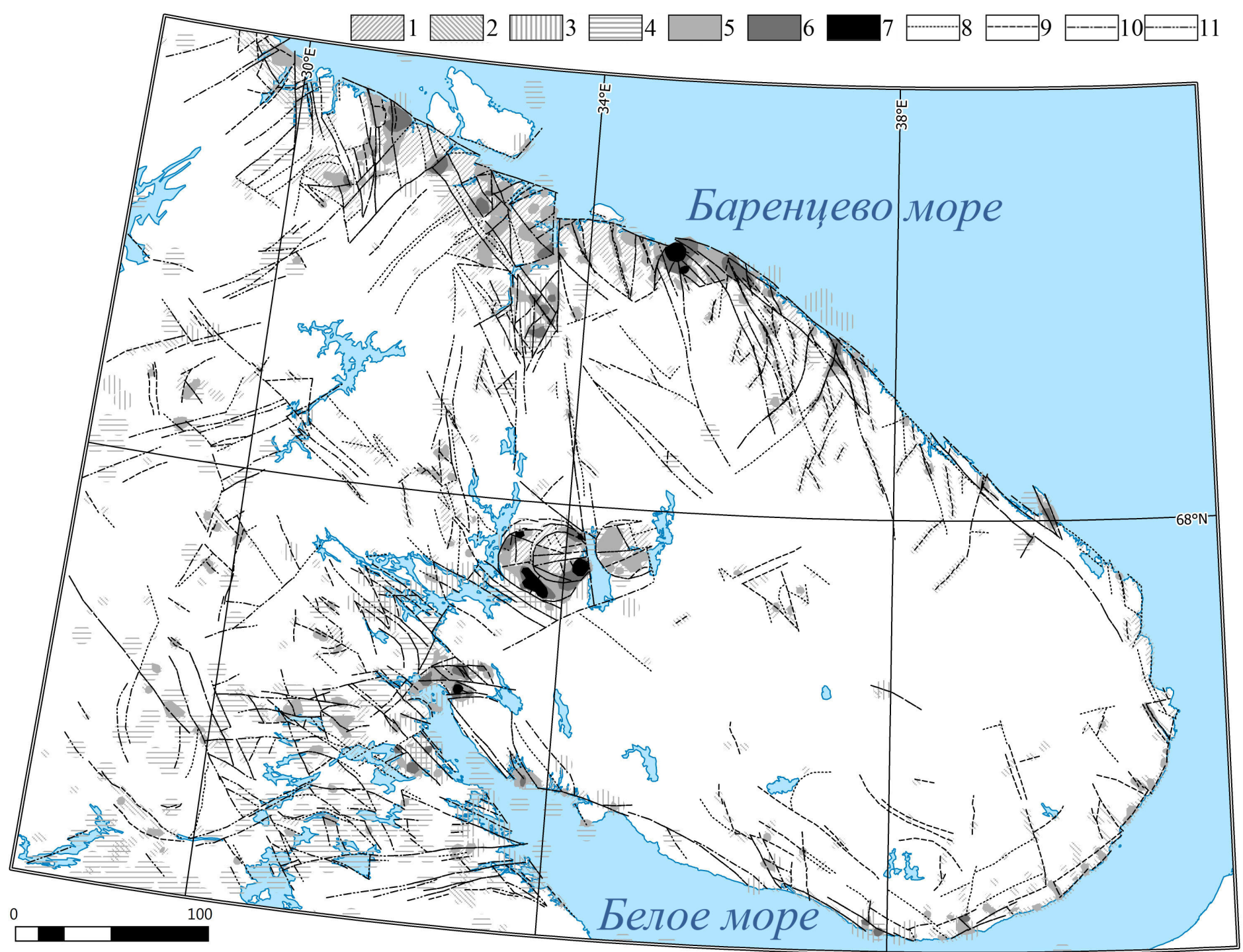

